\title{
Distribution Densities of Hair Follicles in Racehorses
}

\author{
Akiko WATANABE, Nobuyuki KANEMAKI and, Kenji MATSUURA \\ The 3rd Department of Veterinary Internal Medicine, School of Veterinary Medicine, Azabu \\ University, 1-17-71 Fuchinobe, Sagamihara, Kanagawa 229, Japan
}

(Received 16 March 1993/Accepted 16 September 1993)

\begin{abstract}
A study was conducted to determine the integumentary arrangement of hair follicles in racehorses. Seven Thoroughbred horses 4 to 6 years old were surveyed between December, 1991 and March, 1992. The 6-millimeter surgical punch biopsies from 46 sites on the head, neck, trunk and limbs were used to determine the density of hair follicles of each site on the integumentary systems. As a result, the mean number of hair follicles was 810 per square centimeter, and its range was between 525 and 1128. The number of hair follicles digits was larger, and the number of its follicles on pubic, brachial region, and medial region of the knee was smaller, respectively. The density of hair follicles on the ventral sites appeared to be less than that of its follicles in the dorsal sites on the trunk. The hair follicle density of the distal region of the limbs was increased as compared with that of the proximal region.

Key words: apocrine sweat gland, hair follicle, Thoroughbred
\end{abstract}

Jpn. J. Equine Sci. 4(1): 55-60, 1993

The horse is said to be an animal with developed sweat glands which are almost all apocrine sweat glands [8]. Generally, the sweat glands are roughly classified into merocrine sweat glands and apocrine sweat glands. In humans, the merocrine sweat glands exist almost all over the entire body and a large number of apocrine sweat glands exist in the axilla, pudendum and the anus regions. In animals, however, it is known that the merocrine sweat glands are localized in the hairless regions including the footpads of dogs and cats, the surface of the planum and nasolabiale of cattle and ewes, and the frogs of hoofed animals. While, the apocrine sweat glands are distributed over the entire body $[3,5]$.

The ducts of the apocrine sweat glands open into the neck of the hair follicles and the integumentary arrangement of the apocrine sweat glands matches the integumentary arrangement of the hair follicles. The hair follicles of the horse differs from other animals in that there is one hair follicle to one hair root [3, 8, 9]. Therefore, in the distribution of ordinary hair in the horse, the integumentary arrangement of the hair follicles and apocrine glands match each other [1-3, 9].

In the horse, it is said that there are comparatively large number of skin diseases. However, the distribution of ordinary hair, excluding the protective hair and tactile hair of the mane and tail, appears to be uniform but what kind of distribution density is not clear. It is judged that it is important to investigate the distribution of hair follicles in order to learn of the defense system of ordinary hair.

Thereupon, a calculation was made of the hair follicle density of each site of the entire body for a total of 46 sites broadly classified into the 7 sites of the head and neck (2 sites), the thorax (5 sites), the abdomen (8 sites), tail root, the regions of thoracic appendage (13 sites), pelvic regions 
(16 sites) through which a comparative study was made of the differences of the hair follicle density in each of the sites of the entire body.

\section{Materials and Methods}

Animals. Materials were collected from the skins of 7 Thoroughbred racehorses after euthanasia with drugs due to accidents occurring during a race meeting (Table 1). Collection was conducted from December 1991 to March 1992.

After occurrence of the accident and after euthanasia with drugs, fixed area of skin materials were collected using a 6-mm diameter skin biopsy punch (Stiefel Laboratorium) from each of the 46 sites over the entire body which were preserved for 1 or 2 days. After the skin materials were fixed for a whole day and night in 10\% buffered formalin, the number of hair follicles in the punch skin biopsy were counted with a biomicroscope through which the number of hair follicles per $1 \mathrm{~cm}^{2}$ were counted. The location of the skin biopsy, in accordance with the integumentary arrangement

Table 1. Summary of individual signalments

\begin{tabular}{clllll}
\hline Gase No. & Breed & Age & Sex & Color & Body weight $(\mathrm{kg})$ \\
\hline 1 & Thoroughbred & $5 \mathrm{yr}$. & Female & Chestnut & 460 \\
2 & Thoroughbred & $4 \mathrm{yr}$. & Female & Black bay & 428 \\
3 & Thoroughbred & $4 \mathrm{yr}$. & Male & Bay & 464 \\
4 & Thoroughbred & $6 \mathrm{yr}$. & Female & Bay & 448 \\
5 & Thoroughbred & $5 \mathrm{yr}$. & Male & Bay & 490 \\
6 & Thoroughbred & $4 \mathrm{yr}$. & Female & Grey & 446 \\
7 & Thoroughbred & $4 \mathrm{yr}$. & Female & Bay & 440 \\
\hline
\end{tabular}

Table 2. Hair follicle densities of individual integumentary regions in the horse

\begin{tabular}{|c|c|c|c|c|c|}
\hline Division & Region & Hair follicles* $\left(/ \mathrm{cm}^{2}\right)$ & Division & Region & Hair follicles $\left(/ \mathrm{cm}^{2}\right)$ \\
\hline Head & Zygomatic reg & $712 \pm 52.4$ & Abdomen & Xiphoid reg. & $800 \pm 39.2^{\mathrm{ABC}}$ \\
\hline Neck & $\begin{array}{l}\text { Dorsal cervical reg. } \\
\text { Ventral cervical reg. }\end{array}$ & $\begin{array}{l}816 \pm 74.4^{\mathrm{A}} \\
674 \pm 71.4^{\mathrm{B}}\end{array}$ & & $\begin{array}{l}\text { Hypochondriac reg. } \\
\text { Lumbar reg. }\end{array}$ & $\begin{array}{l}868 \pm 81.1^{\mathrm{AB}} \\
929 \pm 58.3^{\mathrm{A}}\end{array}$ \\
\hline Thorax & $\begin{array}{l}\text { Interscapular reg. } \\
\text { Back } \\
\text { Costal reg. } \\
\text { Presternal reg. } \\
\text { Sternal reg. }\end{array}$ & $\begin{array}{l}827 \pm 53.8^{\mathrm{A}} \\
744 \pm 54.7^{\mathrm{AB}} \\
769 \pm 58.3^{\mathrm{AB}} \\
655 \pm 47.4^{\mathrm{B}} \\
782 \pm 52.4^{\mathrm{A}}\end{array}$ & & $\begin{array}{l}\text { Lateral abdominal reg. } \\
\text { Umbilical reg. } \\
\text { Paralumbar reg. } \\
\text { Inguinal reg. } \\
\text { Pubic reg. }\end{array}$ & $\begin{array}{l}810 \pm 72.7^{\mathrm{ABC}} \\
702 \pm 60.6^{\mathrm{C}} \\
822 \pm 28.2^{\mathrm{ABC}} \\
707 \pm 73.7^{\mathrm{BC}} \\
525 \pm 64.0^{\mathrm{D}}\end{array}$ \\
\hline $\begin{array}{l}\text { Regions } \\
\text { of } \\
\text { thoracic } \\
\text { appendage }\end{array}$ & $\begin{array}{l}\text { Scapular reg. } \\
\text { Brachial reg. } \\
\text { Subreg. of humeral } \\
\text { articulation } \\
\text { Cubital subrig. (Medial) } \\
\text { Cubital subrig. (Lateral) } \\
\text { Antebrachial reg. (Medial) } \\
\text { Antebrachial reg. (Lateral) } \\
\text { Carpal reg. (Medial) } \\
\text { Carpal reg. (Lateral) } \\
\text { Metacarpal reg. (Medial) } \\
\text { Metacarpal reg. (Lateral) } \\
\text { Digit (Medial) } \\
\text { Digit (Lateral) }\end{array}$ & $\begin{array}{c}717 \pm 45.5^{\mathrm{D}} \\
624 \pm 47.8^{\mathrm{D}} \\
746 \pm 59.7^{\mathrm{CD}} \\
\\
654 \pm 96.3^{\mathrm{D}} \\
771 \pm 45.7^{\mathrm{CD}} \\
767 \pm 61 \cdot 7^{\mathrm{CD}} \\
\text { l) } 797 \pm 60.5^{\mathrm{CD}} \\
933 \pm 54.8^{\mathrm{BC}} \\
785 \pm 38.4^{\mathrm{CD}} \\
784 \pm 77.0^{\mathrm{CD}} \\
799 \pm 58.9^{\mathrm{CD}} \\
1094 \pm 93.5^{\mathrm{AB}} \\
1107 \pm 73.1^{\mathrm{A}}\end{array}$ & $\begin{array}{l}\text { Pelvic } \\
\text { regions }\end{array}$ & $\begin{array}{l}\text { Sacral reg. } \\
\text { Subreg. of tuber coxae } \\
\text { Gluteal reg. } \\
\text { Subreg. of ischiatic tuber } \\
\text { Trochanteric subreg. } \\
\text { Femoral reg. } \\
\text { Reg. of knee (Medial) } \\
\text { Reg. of knee (Lateral) } \\
\text { Crural reg. (Medial) } \\
\text { Crural reg. (Lateral) } \\
\text { Tarsal reg. (Medial) } \\
\text { Tarsal reg. (Lateral) } \\
\text { Metatarsal reg. (Medial) } \\
\text { Metatarsal reg. (Lateral) } \\
\text { Digit (Medial) }\end{array}$ & $\begin{array}{l}964 \pm 72.5^{\mathrm{B}} \\
884 \pm 64.1^{\mathrm{BC}} \\
834 \pm 56.9^{\mathrm{BC}} \\
746 \pm 53.2^{\mathrm{C}} \\
845 \pm 35.8^{\mathrm{BC}} \\
973 \pm 56.2^{\mathrm{B}} \\
604 \pm 29.3^{\mathrm{D}} \\
942 \pm 54.2^{\mathrm{B}} \\
777 \pm 66.1^{\mathrm{C}} \\
840 \pm 62.6^{\mathrm{BC}} \\
877 \pm 49.6^{\mathrm{BC}} \\
769 \pm 42.9^{\mathrm{C}} \\
837 \pm 43.9^{\mathrm{BC}} \\
845 \pm 76.3^{\mathrm{BC}} \\
934 \pm 61.4^{\mathrm{B}}\end{array}$ \\
\hline Tail & Root of tail & $723 \pm 36.8$ & & Digit (Lateral) & $1128 \pm 71.0^{\mathrm{A}}$ \\
\hline
\end{tabular}

A-CMeans within column subgroups with no co.nmon superscripts differ significantly ( $\mathrm{p} \leqq 0.05)$.

*Mean $\pm \mathrm{SE}(\mathrm{N}=7)$ 


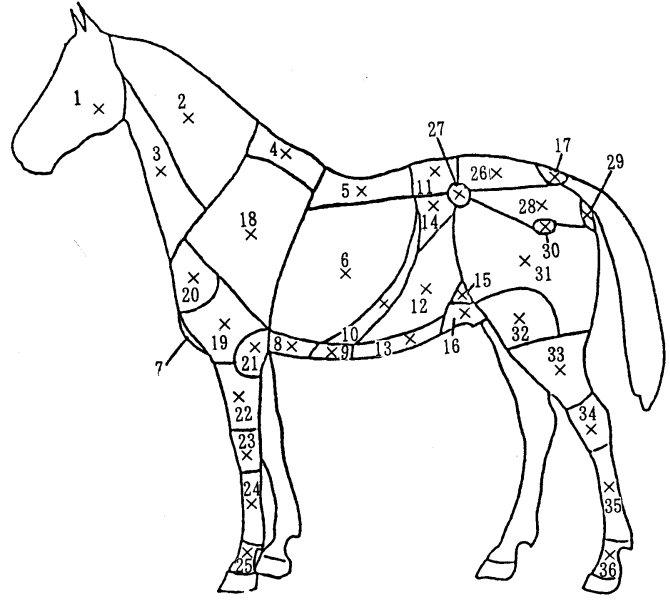

Fig. 1. List of sampling regions* *Adapted from Goody (1972)

1. Head (Zygomatic region)

[Neck]

2. Dorsal cervical region

3. Ventral cervical region

[Thorax]

4. Interscapular region

5. Back

6. Costal region

7. Presternal region

8. Sternal region

[Abdomen]

9. Xiphoid region

10. Hypochonolriac region

11. Lumbar region

12. Lateral abdominal region

13. Umbilical region

14. Paralumbar region

15. Inguinal region

16. Pubic region

17. Tail (Root of tail)

[Regions of thoracic appendage]

18. Scapular region

19. Brachial region

20. Subregion of humeral articulation

21. Cubital subregion

22. Autebrachial region

23. Carpal region

24. Metacarpal region

25. Dight

[Pelvic regions]

26. Sacral region

27. Subregion of tuber coxae

28. Gluteal region

29. Subregion of ischiatic tuber

30. Trochanteric subregion

51. Femoral region

32. Region of knee

33. Crural region

34. Tarsal region

35. Metatarsal region

36. Digit of Goody [4], were the head (zygomatic region), the neck (dorsal cervical region, ventral cervical region), the thorax (interscapular region, back, costal region, presternal region, sternal region), the abdomen (xiphoid region, hypochondriac region, lumbar region, lateral abdominal region, umbilical region, public region), the tail (root of tail), the region of thoracic appendage (scapular region, brachial region, subregion of humeral articulation, cubital subregion, antebrachial region, carpal region, metacarpal region, digit), the pelvic regions (sacral region, subregion of tuber coxae, gluteal region, subregion of ischiatic tuber, trochanteric subregion, femoral region, region of knee, crural region, tarsal region, metatarsal region, digit), as shown in Fig. 1.

Statistical Processing. The comparison of the hair follicle density of the sites within the integumentary arrangement was done using the SAS System (SAS Institute, U.S.A., 1982). In other words, in the comparison between the 2 groups, the TTEST Procedure and in the comparison of 3 , or, more groups, the Duncan's multiple range test of the GLM Procedure were used at $5 \%$ probability.

\section{Results}

The hair follicle density of the 7 sites of the the integumentary system

The mean hair follicle density and its standard error at the 46 sites in the 7 racehorses are given in Table 2.

Head region. Only the zygomatic region of the head region was collected and its mean hair follicle density was 712 .

Neck region. The mean hair follicle density of the neck region was 816 at the dorsal cervical region and 674 at the ventral cervical region. The hair follicle density of the dorsal cervical region was significantly 
higher than the ventral cervical region.

Thorax region. The mean hair follicle density of the abdomen region was 827 at the interscapular region, 744 at the back region, 769 at the costal region, 655 at the presternal region and 782 at the sternal region. The hair follicle density of the presternal region of the ventral cervical region was clearly much lower than the other sites.

Abdomen region. In the abdomen region, the mean hair follicle density of the xiphoid region was 800 , the hypochondriac region 868, the lumbar region 929, the lateral abdominal region 810 , the umbilical region 702 , the paralumbar region 822 , the inguinal region 707 , and the pubic region 525 , with the umbilical region, inguinal region and the pubic region in the ventral region indicating a low hair follicle density.

Tail region. The mean hair follicle density of the root of tail was 723 .

Regions of thoracic appendage. In the regions of thoracic appendage, the mean hair follicle density of the scapular region was 717 , the brachial region 624 , the subregion of humeral articulation 746 , the medial cubital subregion 654, the lateral cubital subregion 771 , the medial antebrachial region 767 , the lateral antebrachial region 797, the medial carpal region 933, the lateral carpal region 785, the medial metacarpal region 784 , the lateral metacarpal region 799, medial carpal region 1094, lateral carpal region 1107 , and the medial and lateral carpal regions indicated a significantly higher hair follicle density than the scapular region, the brachial region and the medial cubital subregion located in the dorsal cervical region.

Pelvic region. In the pelvic region, the mean hair follicle density of the sacral region was 964 , the subregion of the tuber coxae 884, the gluteal region 834 , the subregion

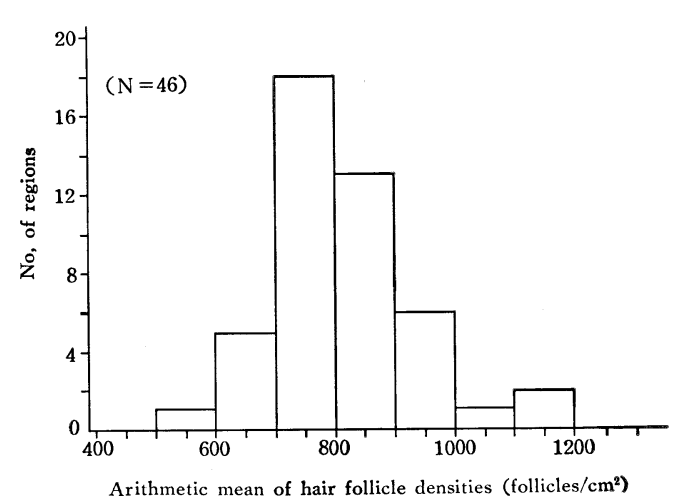

Fig. 2. Histogram of hair follicle densities collected from 46 regions of the integument in 7 racehorses

of ischiatic tuber 746, the trochanteric subregion 845, the femoral region 973, the medial region of knee 604 , the lateral region of knee 942, the medial crural region 777, the lateral crural region 840 , the medial tarsal region 877, the lateral tarsal region 769 , the medial metacarpal region 837, the lateral metacarpal region 1128 . A high hair follicle density was observed in the sacral region and femoral region of the dorsal cervical region and the digits in the distal limbs. And, the difference in hair follicle density of the medial and the lateral sides can be observed in the region of the knee and the digit region and, in either case, the medial hair follicle density was significantly low.

The integumentary arrangement and the extent of dispersion at each site

The integumentary arrangement of the mean hair follicle density of the 7 horses in the 46 sites is given in Fig. 2. The overall mean hair follicle density was 810 and the overall standard of error was 33.2 . The $91 \%$ of the overall material sites indicated a degree of hair follicle density within a range of $600-1,000$ of the 46 sites, the 3 sites of the medial and lateral digits of the regions of thoracic appendage and the lateral digits of the pelvic region indicated 
extremely a high value and an extremely low value in the pubic region (Table 2).

\section{Discussion}

As the seasonal variation [6] of the hair follicle should be excluded, the experiment was restricted to the winter season (from December to March), when the metabolic activity is low. It was found that the distribution of the hair follicles of the skin was not uniform. Especially, the pastern region indicated a high degree of hair follicle density and the pubic region, the brachial region and the medial region of the knee indicated a low degree of density. However, no significant age and sex differences could be made.

In the 8 sections of the head, we collected materials from one site of the zygomatic region. Among the overall 46 sites, this site indicated a mean density of hair follicles. However, there are frequent occurrences of skin diseases of labrum region, lower chin region, auricula region, palpebra in the head sites. The head region suggests that there is a relationship between the sites that require strong protective hair and the thickness of the skin $[1,5,7,8]$. There may have been the necessity of further detailed studies of the head region.

In the neck region, the dorsal cervical region indicated a higher hair follicle density in comparison with the ventral cervial region. The same difference tendencies in hair follicle distribution between the dorsal and the ventral could also be observed in thorax region and the abdomen region. In other words, in the thorax region, the interscapular region indicated a high density and the presternal region indicated a high density. And, in the abdomen, the lumbar region indicated a high density and the presternal region indicated a high density and the umbilical region, inguinal region and the pubic region indicated a low density. From these results, it was thought that such results indicated that the sites of the dorsal cervical region are directly invaded by hazardous materials contained in exposure to ultraviolet rays and infrared rays of the sun and rain. And, the sites of the ventral cervical region which indicate a low density [8] and at the same time, a tendency toward a thin skin was observed in these sites and further, of the entire body, there are also sites of high movability. A thin skin is necessary to increase movability and it is thought that the hair follicle density is low in the ventral cervical region due to the fact that the physical irritation at these sites is lower than other sites.

In the regions of thoracic appendage, significant differences were observed in the carpal region and the pastern region in comparison to other sites. The density in the hair follicle density in both these sites were high and indicated the same tendency as the digit regions of the pelvic regions. And, in the case a comparative study is made of the difference in distribution of hair follicles on the medial and lateral sides of the 4 limbs, a significant difference was observed between the region of knee and the digit and the lateral side indicated a high hair follicle density. The skin in these sites, which indicated higher density of hair follicles, is the closest of the ground, and it receives direct external physical irritation.

The hair follicles of the horse is different from other animals in that the hair follicles do not form a clustering of hair or stapling. Due to this fact, the distribution of hair follicles and the apocrine sweat glands indicated identical distribution $[3,9]$. The distribution of the apocrine sweat glands were not uniform in this study. 
Therefore, the difference of hair follicle density according to the site may attributed to physical protection of the skin against external invasion including physical irritation and chemical protection of the skin through secreting fluid from the sweat glands.

\section{Acknowledgements}

In completion of this paper, deep appreciation and thanks are expressed to Dr. Mikihiro Kaneko, Pathology Division of the Equine Research Institute, Japan Racing Association and the many other researchers who have cooperated in this experiment.

\section{References}

1. Bacha, W. J. Jr. and Wood, L. M. (1990). Color Atlas of Veterinary Histology; pp. 81-109, Lea \& Febiger, Philadelphia.

2. Banks, W. J. (1981). Applied Veterinary Histology, pp. 341-372, Williams \& Wilkins, Baltimore.
3. Dellmann H.-D. and Brown, E. M. (1987). Textbook of Veterinary Histology, 3rd ed., pp. 382415, Lea \& Febiger Philadelphia.

4. Goody, R. C. (1976). Horse Anatomy, pp. 12-13, J. A. Allen, London.

5. Lovell, J. E. and Getty, R. (1957). The hair follicle, epidermis, and skin glands of the dogs. Am. J. Vet. Res. 18: 873-885.

6. Jenkinson, D. M., Loney, C., Elder, H. Y., Montogomery, I., and Mason, D. K. (1989). Effects of season and lower ambient temperature on the structure of the sweat glands in anhidrotic horses. Equine Vet. J. 21: 59-65.

7. Rijko, J. L., Hoover, E. A., and Martin, S. L. (1978). Histologic interpretation of cutaneous biopsies from dogs with dermatologic disorders. Vet. Pathol. 15: 579-589.

8. Talukdar, A. H., Calhoun, M. L., and Stinson, A. W. (1972). Microscopic anatomy of the skin of the horse. Am. J. Vet. Res. 33: 2365-2390.

9. Wakuri, H. (1980). Histology of the Organ of Domestic Animals, pp. 215-224, Gakusosha, Tokyo (in Japanese).

競走馬における体表の毛包分布一一渡辺晶子, 印牧信行, 松浦健二（麻布大学獣医学部 内科学第 3 講座 $=229$ 神奈川県相模原市淵野辺 1-17-71)

競走馬の体表における毛包の分布状態を検討した。すなわち1991年12月から1992年 3 月 までの期間で得た年齢 4 歳から 6 歳のサラブレッド種のウマを供試した。頭部, 頸部, 体 幹扐よび四肢に打沙る皮膚部46位から直径 $6 \mathrm{~mm}$ 径の皮膚パンチ・バイオプシーを実施し， 体表各部位に打将毛包密度を算定した。その結果, 平均毛包密度は $1 \mathrm{~cm}^{2}$ 当たり 810 個 であり，その密度範囲は 525 から1128にあった。また繫部で高毛包密度を示し, 恥骨部, 上腕部および内側後膝部でそれぞれ低密度を示した。体幹の腹側部は背側部より毛包密度 が疎であると推察された。四肢遠位部の毛包密度は，近位部に比べ増加していた。 